\title{
KARAKTERISTIK FISIKO-KIMIA DAN SENSORI KUE STIK IKAN BILIS (STOLEPHORUS HAMILTONII)
}

\author{
Halia Mestagensi ${ }^{1}$, Maherawati ${ }^{1}$, dan Dzul Fadly ${ }^{{ }^{*}}$ \\ ${ }^{1}$ Program Studi Ilmu dan Teknologi Pangan, Fakultas Pertanian, Universitas Tanjungpura \\ Jl. Prof Hadari Nawawi, Kota Pontianak, Kalimantan Barat, Indonesia \\ *Email: dzul.fadly@ faperta.untan.ac.id
}

\begin{tabular}{l}
\hline Article Info \\
\hline Article history: \\
Received July $15^{\text {th }}, 2021$ \\
Revised August $20^{\text {th }}, 2021$ \\
Accepte September $25^{\text {th }}, 2021$
\end{tabular}

\section{Keyword:}

Anchovies; Cake Sticks; Chemical Properties; Sensory Properties

\section{Kata Kunci :}

Ikan Bilis; Kue Stik; Sifat Kimia; Sifat Sensori

\begin{abstract}
Background : Fish stick cracker is diversification of processed fishery products. This study aimed to determine the chemical and sensory characteristics of anchovy-based fish cakes.

Purpose : This study aims to analyze the concentration of anchovies as an additive that produces the best fish sticks based on physicochemical and sensory properties.
\end{abstract}

Method : Penelitian ini adalah studi eksperimen dengan menggunakan Rancangan Acak Kelompok (RAK) dengan 5 taraf perlakuan penambahan ikan bilis $10 \%, 30 \%, 40 \%, 50 \%$, dan $60 \%$ dari jumlah tepung terigu).

Results : Hasil analisis menunjukkan produk terbaik diperoleh pada penambahan ikan bilis sebesar 30\%. Produk ini mengandung air $2,99 \%$, abu 3,10\%, lemak 27,62\%, protein 12,27\%, dan karbohidrat $54,02 \%$, dengan nilai sensori yaitu aroma 3,90 (suka), rasa 3,77 (suka), warna 3,63 (suka), kerenyahan 4,00 (sangat suka).

Conclusion : Anchovies stick products have the potential for diversification of processed fish products.

\begin{abstract}
ABSTRAK
Latar Belakang : Stik ikan merupakan diversifikasi produk olahan hasil perikanan. Penelitian ini bertujuan menentukan karakteristik kimia dan sensori kue stik berbahan dasar ikan bilis.

Tujuan : Penelitian ini bertujuan untuk menganalisis konsentrasi ikan bilis sebagai bahan tambahan yang menghasilkan stik ikan terbaik berdasarkan sifat fisikokimia dan sensori.

Metode : Penelitian ini adalah studi eksperimen dengan menggunakan Rancangan Acak Kelompok (RAK) dengan 5 taraf perlakuan penambahan ikan bilis $10 \%, 30 \%, 40 \%$, 50\%, dan $60 \%$ dari jumlah tepung terigu).

Hasil : Hasil analisis menunjukkan produk terbaik diperoleh pada penambahan ikan bilis sebesar 30\%. Produk ini mengandung air $2,99 \%$, abu 3,10\%, lemak 27,62\%, protein 12,27\%, dan karbohidrat $54,02 \%$, dengan nilai sensori yaitu aroma 3,90 (suka), rasa 3,77 (suka), warna 3,63 (suka), kerenyahan 4,00 (sangat suka).
\end{abstract}

Kesimpulan : Produk stik ikan bilis berpotensi sebagai diversifikasi olahan produk ikan.

\section{PENDAHULUAN}

Stik merupakan kudapan yang banyak dikonsumsi oleh semua kalangan. Makanan kudapan berbahan dasar terigu, tepung sagu atau tepung tapioka, telur, lemak, dan air, yang dicirikan oleh bentuknya pipih dan 
memanpanjang (Pratiwi, 2013). Walaupun bukan makanan utama, kudapan bisa dijadikan alternatif untuk meningkatkan asupan zat gizi dengan melakukan substitusi bahan pangan kaya gizi terhadap bahan dasarnya (Mills et al., 2018), salah satunya adalah dengan menggunakan ikan.

Stik ikan adalah salah satu kudapan dengan bahan pembuatannya sama dengan stik pada umumnya, yang mana hanya dengan dengan penambahan ikan. Olahan stik adalah salah satu bentuk diversifikasi hasil olahan pangan. Stik juga merupakan produk olahan ekstrudat, makanan yang dihasilkan melalui proses ektruksi berbahan dasar tepung-tepungan atau pati dengan penambahan bahan makanan lain diproduksi dengan ataupun tanpa proses penggorengan (BSN, 2000).

Ikan bilis merupakan jenis ikan pelagis populer di Indonesia, berukuran 6-9 cm, dan hidup berkelompok di daerah perairan dangkaldengan kadar garam 10-15 g/kg (Effendi, 2002). Ikan pelagis kecil ini memiliki ciriciri badan memanjang dan pipih berwarna agak bening dengan garis putih memanjang ditengah tubuhnya (Lubis et al., 2021). Ikan bilis dijadikan produk stik ikan karena memiliki nilai gizi dengan protein tinggi yang baik bagi tubuh, disukai masyarakat, dan ekonomis. Penggunaan ikan bilis pada pembuatan stik diharapkan menjadi salah satu potensi untuk menambah nilai tambah ikan bilis.

Penelitian ini bertujuan untuk menganalisis konsentrasi ikan bilis sebagai bahan tambahan yang menghasilkan stik ikan terbaik berdasarkan sifat fisikokimia dan sensori.

\section{METODE PENELITIAN}

Penelitian ini bertempat di Laboratorium Desain Pangan dan Laboratorium Kimia Pangan, Fakultas Pertanian, Universitas Tanjungpura, Pontianak, selama 6 bulan. Bahan utama adalah ikan bilis (Stolephorus Hamiltonii) yang diperoleh dari pasar tradisional di Kubu Raya, Kalimantan Barat, tepung terigu (merk Kunci Biru), tepung tapioka (merk Rose Brand), dan bahan komplementer berupa garam, baking powder, air, bawang putih, telur, bawang merah, margarin, dan minyak goreng.

\section{Rancangan penelitian}

Rancangan Acak Kelompok (RAK) 1 faktor digunakan pada penelitian ini, yaitu persentase penambahan ikan bilis dengan 5 taraf. Taraf perlakuan yang dilakukan dalam penelitian ini yaitu :

$\mathrm{p} 0=$ Kontrol (tanpa ikan bilis)

p1= Penambahan ikan bilis $30 \%$

p2 $=$ Penambahan ikan bilis $40 \%$

p3= Penambahan ikan bilis 50\%

p4= Penambahan ikan bilis $60 \%$

\section{Preparasi produk}

Pembuatan stik ikan bilis mengacu pada penelitian Fitri et al. (2016) yang modifikasi. Preparasi produk melalui 8 tahap, yaitu: (1) Ikan dibersihkan dan bagian yang tidak digunakan disisihkan (ekor, kepala, dan isi perut). (2) Pelumatan ikan dengan mesin penggiling daging. (3) Pembuatan adonan dengan persentase ikan bilis yaitu 0\%, 30\%, 40\%, 50\%, dan 60\% dari jumlah tepung terigu (250 g), (4) Penambahan bahan komplementer, yaitu 1 butir telur, $10 \mathrm{~g}$ bawang merah, $10 \mathrm{~g}$ bawang putih, $5 \mathrm{~g}$ garam, $50 \mathrm{~g}$ margarin, $0,5 \mathrm{~g}$ baking powderg, $250 \mathrm{~g}$ tepung terigu,10 g tepung tapioka, serta air (penambahan air yg berbeda setiap perlakuan yaitu $40 \mathrm{ml}, 30 \mathrm{ml}, 20 \mathrm{ml}, 10 \mathrm{ml}, 5 \mathrm{ml}$ ). (5) Homohegisasi. (6) Pembentukan adonan lembaran tipis serta pencetakan stik ikan menggunakan ampia (tebal $\pm 3 \mathrm{~mm}$ dan panjang $8-10 \mathrm{~cm}$. (7) Proses penggorengan stik ikan dengan suhu $170{ }^{\circ} \mathrm{C}$ dalam $1 \mathrm{~L}$ minyak sawit hingga berwarna kuning kecokelatan $( \pm 3$ menit). (8) Penirisan dan pendinginan selama 5 menit pada suhu ruang.

\section{Determinasi sifat kimia dan sensori produk}

Produk kue stik ikan yang telah dipreparasi kemudian dianalisis sifat kimia berupa kadar abu, air, lemak, protein, dan karbohidrat dengan mengacu pada metode (AOAC, 2012). Kemudian sifat sensori produk ditentukan oleh 30 panelis tidak terlatih terhadap aroma, warna, rasa, dan kerenyahan melalui uji hedonik (Fadly \& Purwayantie, 2019).

\section{Analisis Data}

Uji ANOVA (Analysis of Variance) pada taraf 5\% diterapkan dalam analisis data pada penelitian ini, dengan uji Beda Nyata Jujur (BNJ) pada taraf $5 \%$ sebagai uji lanjut. Uji Friedman Apriyantono et al. (1989) 
digunakan dalam menganalisis hasil uji hedonik. Kemudian, Uji indeks efektifitas De Garmo et al. (1984) dilakukan dalam penentuan produk terbaik.

\section{HASIL DAN PEMBAHASAN PENELITIAN}

Hasil determinasi sifat kimiawi produk kue stik ikan bilis disajikan pada Tabel 1. Sifat sensori produk melalui uji hedonik dapat dilihat pada Tabel 2. Selanjutnya nilai indeks efektifitas masing-masing formulasi tersaji pada Tabel 3 .

Tabel 1. Nilai Kimiawi Kue Stik Ikan Bilis

\begin{tabular}{cccccc}
\hline Ikan Bilis (\%) & Air & Abu & Lemak & Protein & Karbohidrat \\
\hline 0 (kontrol) & $2,74^{\mathrm{ab}} \pm 0,15$ & $2,63^{\mathrm{a}} \pm 0,25$ & $31,04^{\mathrm{c}} \pm 0,61$ & $8,89^{\mathrm{a}} \pm 0,12$ & $54,70^{\mathrm{b}} \pm 0,71$ \\
30 & $2,99^{\mathrm{b}} \pm 0,44$ & $3,10^{\mathrm{b}} \pm 0,03$ & $27,62^{\mathrm{a}} \pm 0,49$ & $12,27^{\mathrm{b}} \pm 0,15$ & $54,02^{\mathrm{b}} \pm 0,24$ \\
40 & $2,43^{\mathrm{a}} \pm 0,22$ & $3,69^{\mathrm{c}} \pm 0,05$ & $29,47^{\mathrm{b}} \pm 0,37$ & $12,37^{\mathrm{bc}} \pm 0,42$ & $52,04^{\mathrm{a}} \pm 0,75$ \\
50 & $2,92^{\mathrm{ab}} \pm 0,12$ & $3,52^{\mathrm{c}} \pm 0,16$ & $30,17^{\mathrm{bc}} \pm 0,61$ & $13,21^{\mathrm{c}} \pm 0,40$ & $50,18^{\mathrm{a}} \pm 0,95$ \\
60 & $3,15^{\mathrm{b}} \pm 0,38$ & $3,48^{\mathrm{c}} \pm 0,22$ & $30,01^{\mathrm{bc}} \pm 0,27$ & $12,72^{\mathrm{bc}} \pm 0,55$ & $50,64^{\mathrm{a}} \pm 1,06$ \\
\hline $\begin{array}{c}\boldsymbol{P} \text {-value } \\
(\boldsymbol{\alpha}=\mathbf{0 . 0 5})\end{array}$ & 0,005 & 0,003 & 0,009 & 0.008 & 0,017 \\
\hline
\end{tabular}

Tabel 2. Nilai Sensori Kue Stik Ikan Bilis

\begin{tabular}{ccccc}
\hline $\begin{array}{c}\text { Penambahan } \\
\text { Ikan Bilis (\%) }\end{array}$ & Aroma & Warna & Rasa & Kerenyahan \\
\hline 0 (kontrol) & 3,77 & 4,30 & 3,47 & 3,30 \\
30 & 3,90 & 3,63 & 3,77 & 4,00 \\
40 & 3,50 & 3,37 & 3,50 & 3,80 \\
50 & 3,33 & 2,97 & 3,47 & 3,70 \\
60 & 3,27 & 2,80 & 3,30 & 0.004 \\
\hline P-value $(\boldsymbol{\alpha}=\mathbf{0 . 0 5})$ & 0.002 & 0.000 & 0.167 & 0.63 \\
\hline
\end{tabular}

Tabel 3. Nilai Indeks Efektifitas

\begin{tabular}{cc}
\hline Penambahan Ikan Bilis (\%) & Nilai Perlakuan \\
\hline 0 (kontrol) & 0,42 \\
30 & 0,76 \\
40 & 0,60 \\
50 & 0,41 \\
60 & 0,26 \\
\hline
\end{tabular}

\section{Sifat Kimiawi}

Kadar air stik ikan bilis pada penelitian ini berkisar antara 2,43-3,15\%. Kadar air stik ikan bilis yang dihasilkan telah sesuai SNI 01-2886-2000 ( $\leq 4 \%$ ). Perbedaan penambahan ikan bilis signifikan berpengaruh terhadap kadar air produk. Semakin banyak ikan bilis yang ditambahkan semakin meningkatkan kadar air stik ikan tersebut, ini disebabkan oleh tingginya kandungan air pada ikan bilis.

Kadar abu stik ikan berkisar antara 2,63-3,69\%. Kadar abu stik ikan dengan penambahan ikan bilis lebih tinggi dibandingkan dengan kontrol (tanpa penambahan ikan bilis). Kadar abu stik ikan dalam semua penelitian ini tidak memenuhi standar kadar abu stik ikan menurut BSN (2000) yaitu maksimum $1 \%$. Penambahan ikan bilis signifikan mempengaruhi kadar abu produk, oleh sebab penggunakan ikan bilis bersama dengan tulangnya. Meningkatnya kadar abu dengan adanya penambahan ikan bilis pada stik memberikan nilai tambah yaitu adanya penambahan kandungan mineral berupa kalsium dan fosfor yang terdapat pada tulang ikan (Martínez-Valverde et al., 2000; Nawaz et al., 2019), yang berguna dalam proses pertumbuhan serta pemeliharaan tulang dan gigi (Campbell, 2001; Greer \& Krebs, 2006; Li et al., 2018).

Produk stik ikan mengandung protein 8,89-13,21\%. Kadar protein stik ikan dengan penambahan ikan bilis lebih tinggi dibandingkan dengan kontrol (tanpa penambahan ikan bilis). Kadar protein stik ikan dalam semua penelitian ini telah memenuhi standar SNI 01-2886-2000 $\geq 5 \%$. Pada Tabel 1, diketahui bahwa 
penambahan ikan bilis menunjukkan perbedaan signifikan terhadap kadar protein stik, hal ini diduga semakin banyak ikan bilis yang ditambahkan semakin meningkatkan kadar protein stik ikan. Hal ini disebabkan oleh kandungan protein ikan bilis yang tinggi sehingga penambahan ikan ini semakin meningkatkan kadar protein pada stik.

Kadar lemak kue stik ikan ini berkisar antara 27,62-31,04\%. kadar lemak stik dengan penambahan ikan bilis pada setiap perlakuan masih dalam kisaran normal. Kadar lemak tertinggi adalah pada formulasi dengan $50 \%$ ikan bilis, dan terendah adalah formulasi dengan 30\% ikan bilis. Diduga perbedaan kadar lemak pada setiap perlakuan tidak berbeda signifikan akibat penyerapan minyak dalam proses penggorengan oleh tepung terigu. Kadar lemak stik ikan dalam semua penelitian ini telah memenuhi standar mutu SNI 01-2886-2000 yaitu $\leq 38 \%$ dengan proses penggorengan.

Tabel 1 menunjukkan bahwa hasil kadar karbohidrat stik ikan berkisar antara 50,18-54,70\%. Kadar karbohidrat stik ikan pada perlakuan kontrol (tanpa penambahan ikan bilis) lebih tinggi dibandingkan dengan perlakuan penambahan ikan bilis. Pada penelitian ini, semakin banyak ikan bilis yang ditambahkan semakin menurunkan kadar karbohidrat, hal ini diduga karena tingkat proporsi bahan baku utama yaitu tepung terigu yang semakin menurun dengan adanya penambahan ikan bilis.

\section{Sifat Sensori}

Tabel 2 menunjukkan bahwa penambahan ikan bilis pada stik pada persentase tertentu memberikan pengaruh signifikan terhadap aroma, warna dan kerenyahan stik ikan, namun tidak signifikan mempengaruhi rasa.

Nilai aroma memberikan pengaruh signifikan terhadap stik dikarenakan semakin meningkatnya persentase ikan bilis yang ditambahkan maka stik yang dihasilkan akan semakin memberikan aroma khas ikan.

Nilai warna signifikan mempengaruhi kesukaan terhadap stik ikan. Hasil uji kesukaan menunjukkan bahwa semakin tinggi penambahan ikan bilis akan nilai kesukaan akan semakin rendah karena timbulnya warna yang semakin kusam. Menurut Prabowo (2010), kandungan mineral yang tinggi pada pangan akan menimbulkan warna yang semakin gelap. Pada penelitian ini, penggunaan ikan bilis beserta dengan tulangnya akan berkontribusi terhadap peningkatan jumlah mineral dan warna gelap.

Nilai rasa tidak signifikan mempengaruhi peneimaan stik ikan. Hal ini diduga semakin meningkatnya persentase ikan bilis yang ditambahkan maka stik yang dihasilkan semakin memiliki rasa amis atau khas ikan yang kuat sehingga membuat panelis tidak menyukai rasa dari stik.

Nilai kerenyahan secara signifikan mempengaruhi penerimaan stik ikan yang dihasilkan. Berdasarkan hasil uji kesukaan, stik dengan penambahan ikan bilis menghasilkan tingkat kerenyahan yang dapat diterima oleh panelis. Penambahan ikan bilis pada kelima taraf menghasilkan tingkat kerenyahan yang relatif sama

\section{Penentuan Perlakuan Terbaik}

Nilai perlakuan tertinggi stik ikan bilis adalah pada persentase $30 \%$ ikan bilis. Formulasi ini menghasilkan nilai air 2,99\%, abu 3,10\%, protein 12,27\%, lemak 27,62\% dan kadar karbohidrat (54,02\%). Hasil uji sensoris produk ini yaitu warna $=3,63$, aroma $=3,90$, rasa $=3,77$, dan kerenyahan $=4,00$.

\section{KESIMPULAN}

Penggunaan bahan baku ikan bilis dengan kadar yang berbeda dalam pembuatan stik mempengaruhi sifat kimiawi (protein, abu, karbohidrat, air, dan lemak). Ikan bilis juga mempengaruhi aroma, warna, rasa dan kerenyahan pada stik ikan. Dari hasil penelitian perlakuan penambahan ikan bilis $30 \%$ merupakan perlakuan terbaik, dengan kadar air 2,99\%, kadar abu 3,10\%, kadar lemak 27,62\%, kadar protein 12,27\%, kadar karbohidrat 54,02\%; dan tingkat kesukaan berupa aroma $=3,90$ (suka), warna $=3,63$ (suka), rasa $=3,77$ (suka), dan kerenyahan $=4,00$ (sangat suka).

\section{SARAN}

Saran penelitian ini yaitu perlu diteliti lebih lanjut kandungan mineral pada stik ikan bilis. 


\section{DAFTAR PUSTAKA}

AOAC. (2012). Official methods of analysis, 19th edition. Association of Official Analytical Chemists (Official methods 968.08, 956.01, and 968.08.).

Apriyantono, A., Fardiaz, Puspitasari, N. L., Sedamawati, \& Budiyanto, S. (1989). Analisis Bahan Pangan. IPB Press.

BSN. (2000). Tentang Makanan Ekstrudat. Badan Standardisasi Nasional.

Campbell, J. D. (2001). Lifestyle, minerals and health. Medical Hypotheses, 57(5), 521-531. https://doi.org/10.1054/mehy.2001.1351

De Garmo, P., Sullivan, W. G., \& Canada, J. R. (1984). Engineering Economy (7th ed.). Macmilan Publishing Comp.

Effendi. (2002). Biologi Perikanan. Yayasan Pustaka.

Fadly, D., \& Purwayantie, S. (2019). Karakteristik Sensori dan Kimiawi Non-Meat Burger Patties Berbasis Kearifan Pangan Lokal. Ghidza: Jurnal Gizi Dan Kesehatan, 3(1), 19-24.

Fitri, A., Anandito, R. B. K., \& Siswanti, S. (2016). Penggunaan Daging Dan Tulang Ikan Bandeng (Chanos chanos) pada Stik Ikan Sebagai Makanan Ringan Berkalsium Dan Berprotein Tinggi. Jurnal Teknologi Hasil Pertanian, 9(2), Article 2. https://doi.org/10.20961/jthp.v9i2.17468

Greer, F. R., \& Krebs, N. F. (2006). Optimizing Bone Health and Calcium Intakes of Infants, Children, and Adolescents. Pediatrics, 117(2), 578-585. https://doi.org/10.1542/peds.2005-2822

Li, K., Wang, X.-F., Li, D.-Y., Chen, Y.-C., Zhao, L.-J., Liu, X.-G., Guo, Y.-F., Shen, J., Lin, X., Deng, J., Zhou, R., \& Deng, H.-W. (2018). The good, the bad, and the ugly of calcium supplementation: A review of calcium intake on human health. Clinical Interventions in Aging, 13, 2443-2452. https://doi.org/10.2147/CIA.S157523

Lubis, E. K., Sinaga, T. Y., \& Susiana, S. (2021). Inventarisasi Ikan Demersal dan Ikan Pelagis yang Didaratkan di PPI Kijang Kecamatan Bintan Timur Kabupaten Bintan. Jurnal Akuatiklestari, 4(2), 47-57. https://doi.org/10.31629/akuatiklestari.v4i2.2536

Martínez-Valverde, I., Jesús Periago, M., Santaella, M., \& Ros, G. (2000). The content and nutritional significance of minerals on fish flesh in the presence and absence of bone. Food Chemistry, 71(4), 503-509. https://doi.org/10.1016/S0308-8146(00)00197-7

Mills, S. R., Wilcox, C. R., Ibrahim, K., \& Roberts, H. C. (2018). Can fortified foods and snacks increase the energy and protein intake of hospitalised older patients? A systematic review. Journal of Human Nutrition and Dietetics, 31(3), 379-389. https://doi.org/10.1111/jhn.12529

Nawaz, A., Xiong, Z., Xiong, H., Chen, L., Wang, P., Ahmad, I., Hu, C., Irshad, S., \& Ali, S. W. (2019). The effects of fish meat and fish bone addition on nutritional value, texture and microstructure of optimised fried snacks. International Journal of Food Science \& Technology, 54(4), 1045-1053. https://doi.org/10.1111/ijfs.13974

Prabowo, B. (2010). Kajian Sifat Fisikokimia Tepung Millet Kuning dan Tepung Millet Merah [Skripsi]. Universitas Sebelas Maret Surakarta.

Pratiwi, F. (2013). Pemanfaatan Tepung Daging Ikan Layang Untuk Pembuatan Stik Ikan [Skripsi]. Universitas Negeri Semarang. 